UDC 664 (061.1 €C)

JEL Classification: Q11, 013

DOI: https://doi.org/10.32317/2221-1055.201905087

Jadwiga DROŻDŻ

\title{
Development of the food industry in Poland during the membership in the European Union
}

\begin{abstract}
The purpose of the article is to present the impact of Poland's membership in the European Union on the development of production of food, beverages and tobacco products.

Research methods. In the research process were used such methods as: abstract and logical for presentation of the state of the Polish food industry after fifteen years of membership in the European Union; system analysis with using the mathematic methodology for analysis of the dynamics of the food industry development against the background of changes in the market environment; induction and deduction for identifying factors determining the development of the food sector (with attention to the impact of membership in the European Union) and the assessment of the position of Polish food producers in the food industry of the European Union.

Research results. An economic evaluation of the Polish food industry in comparison to the countries of the European Union was made. Development rate of the food industry during the Polish membership in the European Union was relatively high but generally lower than in the whole industry. Over the analysed period (2004-2018), the food production increased by $4.2 \%$, in average, while for the whole industry the same rate was estimated in $5.5 \%$. The Polish food industry occupies the sixth position according to the trade value determined by the purchasing power of currencies, after the German, French, Italian, English and Spanish industries. After the integration with the EU, a position of the Polish food industry has remained unchanged, but the distance between our food industry and the largest food producers in the European Union has been clearly diminished. Currently, around $9 \%$ of the EU food are produced in Poland, with the share in the population potential of about 7.5\% and, in the economic potential - of about 3\% (measured by the share of GDP in the EU). In 2017, a value of the food industry's turnover in Poland was 40-43\% lower than in Germany and France, 20-25\% lower than in Spain and Italy and 5\% lower than in the United Kingdom. The development rate of the food industry in Poland was one of the faster rates among the EU countries, twice as fast as the European Union in average, and also higher than in the EU-13.

Elements of scientific novelty. Scientific novelty of the article lies in the revealing of development of the food industry of Poland in terms of European integration.

Practical significance. The research results can be used by the food sector, operators and agricultural enterprises of the EU and Ukraine. Tabl.: 2. Figs.: 2. Refs.: 9.

Keywords: food industry; food products; beverages and tobacco products; sold production of the food industry; Poland; European Union.
\end{abstract}

Drożdż Jadwiga - assistant of the department of food industry economics, Institute of Agricultural and Food Economics - National Research Institute (20, Swietokrzyska Str., Warsaw, Poland)

E-mail: jadwiga.drozdz@ierigz.waw.pl

Scientific problem. The objective of the article is to present the impact of the Poland's membership in the European Union on the development of production of food products, beverages and tobacco products. The growth rate of the food sector has been confronted with the development rate of the industry and the whole national economy. The diversification of development in the individual periods and types of processing has been indicated and those studies have been complemented by a comparison of the rate of changes in the Polish food industry with changes in other EU countries. This allowed to determine the position of

(c) Jadwiga Drożdż, 2019
Polish food producers in the EU food industry both after entering of Poland in the European Union and in recent years.

The development of food business enterprises depends not only on production factors (i.e. labour or capital), but also on external factors such as the rate of economic development, rate of its transformation and ability to adapt to new conditions. There is also a group of so-called internal factors such as the quality and stability of the commodity offer, the level of costs and prices, the economic strength of companies and their market efficiency, which determine the development of the sector [4]. Exogenous factors are shaped randomly or by other policymakers, and the operator must take them into account and be 
completely subordinate to them, while internal factors to some extent depend on producers (e.g. on their operability or ability to predict future operating conditions).

Analysis of recent research and publications. The article contains the results of scientific research carried out as part of the implementation of the study "Structural changes of the domestic food industry in a changing market environment", part of the research topic "Evolution and Perspectives of Agri-Food Markets" implemented under the Multiannual Program "Polish Agriculture and EU 2020+". challenges, opportunities, threats, proposals " at the Institute of Agricultural and Food Economics - National Research Institute. The research problem addressed in this article was initiated by the author and other collaborators of the Institute (Dr. Robert Mroczek, Mirostawa Tereszczuk) in earlier years, but concerned a shorter period, and the approach to the problem was more detailed, as the changes at the level of individual industries of the food industry were examined. The results of these works contain monographs included in the list of literature as positions [3], [5], [6] and [7], which were used as a basis in the analysis of the phenomenon under investigation. This study is an attempt to assess changes that have occurred in the Polish food industry after 15 years of membership in the European Union, determine the factors determining its development and the position of Polish food producers in the European Union food industry.

The purpose of the article is to present the impact of the Poland's membership in the European Union on the development of production of food products, beverages and tobacco products.

Research results.

Material and research methodology

The source material used in these studies was the published and unpublished data from the CSO, Eurostat and Ministry of Finance. The studies refer to the years 2004-2018. To assess the development rate of the sector and the whole economy and some elements of the market environment, classic tools of ratio analysis have been used. The rate of changes in the individual market elements has been presented in constant prices and these changes have been presented as arithmetic means for three-year subperiods. The variability of production sold of the food industry in Poland and other EU countries has been presented by means of the annual average rate of changes, using the trend function linear regression analysis (in absolute terms) or the compound interest formula [8] (in relative terms).

$\mathrm{K}_{\mathrm{n}}=\mathrm{K}_{\mathrm{o}} \times(1+\mathrm{r} / 100)^{\mathrm{n}-1} \mathrm{r}=\left(\sqrt[n-1]{\frac{K n}{K o}}-1\right) \times 100$,

where: $K_{n}$ - value of the feature in the end period,

$\mathrm{K}_{\mathrm{o}}$ - value of the feature in the beginning period,

$r$ - growth rate, annual average rate of changes.

1. Development of the food sector in Poland

The development rate of the food industry during the Polish membership in the European Union was relatively high but generally lower than of the whole industry (Table 1). Over the analysed period, the production of this sector increased by, on average, $4.2 \%$ a year when compared to $5.5 \%$ for the whole industry. The exception were both the years of the global economic crisis, when a slowdown occurred, but nevertheless food producers coped better with the difficult economic situation when compared to other industries, and the years 2013-2015. In the years of crisis, the development rate of the food industry was by $0.5 \%$ higher than in the whole industry. The food industry was growing fastest in the first years of membership and in the last three years of the analysed period. The value of production sold in these subperiods was growing by, on average, $5.4 \%$ a year. However, it should be pointed out that the development of the food sector in the years 2016-2018 was somewhat ahead of the development rate of the whole industry. The development of food production was relatively permanent, while that of beverages and tobacco products was half slower and characterised by the high variability. In some years, there was also a regress in the production of beverages and tobacco products.

The consequence of such changes in both the food industry and its market environment after the integration with the European Union was the increase in the production of food, beverages and tobacco products at constant prices, by around $80 \%$, with the increase in the total industry by $95 \%$. The increase in the production of the food industry during the analysed period was by $8 \%$ higher than that of gross domestic product. At the same time, it was much larger than that of the agricultural commodity production, which increased only 
by $1 / 3$, and took place with a minimum increase in the consumption of food, beverages and tobacco products. As a result, the food industry continues to strengthen its position in the food sector and increases its share in meeting the domestic food demand. At the same time, its position in the Polish industry and the whole economy is growing weaker, which is mainly related to the change in consumption patterns.

Table 1. Comparison of the pace of development of food industry production in Poland and its market environment (in percent)

\begin{tabular}{|c|c|c|c|c|c|c|c|}
\hline \multirow[t]{2}{*}{ Specification } & $\begin{array}{l}2004- \\
2006\end{array}$ & $\begin{array}{l}2007- \\
2009\end{array}$ & $\begin{array}{l}2010- \\
2012\end{array}$ & $\begin{array}{l}2013- \\
2015\end{array}$ & $\begin{array}{l}2016- \\
2018^{a}\end{array}$ & $\begin{array}{l}2004- \\
2018^{\mathrm{a}}\end{array}$ & \multirow{2}{*}{ 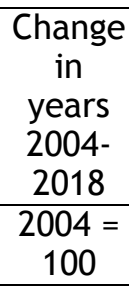 } \\
\hline & \multicolumn{6}{|c|}{ on average per year in percent } & \\
\hline $\begin{array}{l}\text { Increase in sold production: } \\
\text { - food products } \\
\text { - beverages } \\
\text { - tobacco products } \\
\text { Total food industry products }\end{array}$ & $\begin{array}{r}5,7 \\
-2,4 \\
5,4 \\
\end{array}$ & $\begin{array}{r}3,9 \\
4,1 \\
-5,4 \\
3,8 \\
2\end{array}$ & $\begin{array}{l}5,1 \\
-1,0 \\
0,5 \\
4,3 \\
57\end{array}$ & $\begin{array}{l}2,5 \\
0,1 \\
5,3 \\
2,0\end{array}$ & $\begin{array}{c}5,8 \\
0,6 \\
12,1 \\
5,4 \\
5\end{array}$ & $\begin{array}{l}4,6 \\
1,9 \\
2,1 \\
4,2\end{array}$ & $\begin{array}{l}188,3 \\
125,2 \\
116,8 \\
179,3 \\
1052\end{array}$ \\
\hline Industrial production & 9,3 & 3,3 & & 4,0 & 5,2 & & 195,2 \\
\hline $\begin{array}{l}\text { Commodity production of } \\
\text { agriculture }\end{array}$ & 1,0 & 3,6 & 1,1 & 2,0 & $4,3^{b}$ & $2,3^{c}$ & $131,7^{c}$ \\
\hline GDP & 4,9 & 4,6 & 3,4 & 2,8 & 4,3 & 4,0 & 171,4 \\
\hline $\begin{array}{l}\text { Consumption of food and } \\
\text { non-alcoholic beverages } \\
\text { Consumption of alcoholic }\end{array}$ & 2,4 & 1,4 & $-1,3$ & $-0,4$ & $2,9^{b}$ & $0,8^{c}$ & $109,7^{c}$ \\
\hline beverages and tobacco products & 3,7 & 6,8 & $-0,5$ & $-8,5$ & $2,7^{b}$ & $0,7^{c}$ & $102,2^{c}$ \\
\hline $\begin{array}{l}\text { Retail sale of food products } \\
\text { and non-alcoholic beverages }\end{array}$ & 0,3 & 0,8 & $-1,1$ & 0,0 & $2,0^{\mathrm{b}}$ & $0,3^{c}$ & $102,9^{c}$ \\
\hline $\begin{array}{l}\text { Retail sale of alcoholic beverages } \\
\text { and tobacco products }\end{array}$ & 1,8 & 2,7 & $-1,7$ & $-3,5$ & $2,8^{\mathrm{b}}$ & $0,3^{c}$ & $100,7^{c}$ \\
\hline $\begin{array}{l}\text { Exports of food industry products } \\
\text { Imports of food industry products }\end{array}$ & $\begin{array}{l}30,1 \\
24,5\end{array}$ & $\begin{array}{c}9,5 \\
14,6\end{array}$ & $\begin{array}{l}16,4 \\
13,0\end{array}$ & $\begin{array}{c}10,0 \\
5,9\end{array}$ & $\begin{array}{l}9,5 \\
7,1\end{array}$ & $\begin{array}{l}15,1 \\
13,0\end{array}$ & $\begin{array}{l}603,0 \\
479,9\end{array}$ \\
\hline $\begin{array}{l}\text { Share of export growth in growth } \\
\text { production of the food industry } \\
\text { (in percent) }\end{array}$ & 57,1 & 81,4 & 41,1 & 868,9 & 66,8 & 67,6 & (110, \\
\hline
\end{tabular}

a data for 2018 are estimates, b changes in years 2016-2017, c changes in years 2004-2017

Source: own study based on Eurostat and GUS data published in the Statistical Yearbooks of the Republic of Poland from 2010-2018, Warsaw.

After years of the high absorption capacity of the domestic market (in the 90s), the development of domestic demand for food, beverages and tobacco products has been weakened. The individual consumption of these products was relatively stable or even declined in some years. Therefore, the export [5,6] became a basis for the development of the food industry in Poland in the last fifteen years. The value of food industry semi-finished products and products placed on foreign markets increased six times and its share in the sector's sales increased to around 43\% (Figure 1) - this indicator is more than three times higher than before entering of Poland in the European Union. At this time, the value of imported food industry semi-finished and finished products increased more than four times, which means the average increase by $7.1 \%$ a year, with the increase in the export by $9.5 \%$. The result of such rate of turnover of foreign trade in food products was the twelve-fold increase in the trade balance of these commodities. In the years 20042018 , around $67 \%$ of the increase in production sold of the food industry were placed in foreign markets, which means that without the development of export as a result of integration with the European Union, the increase in the sector's production would be small.

Food industry companies have made good use of the opportunity which has been opened up for them after the accession of Poland to the European Union [3]. Their comparative advantages [9] in a form of, inter alia, lower labour payments, lower prices of raw materials (though not always and not all) allowed the sector to grow rapidly. It is important that these advantages are slowly disappearing, and 
that the factor that will effectively compensate them in order to maintain our competitiveness in foreign markets, are non-price competition instruments, such as the increasing labour productivity and quality of offered products [2].

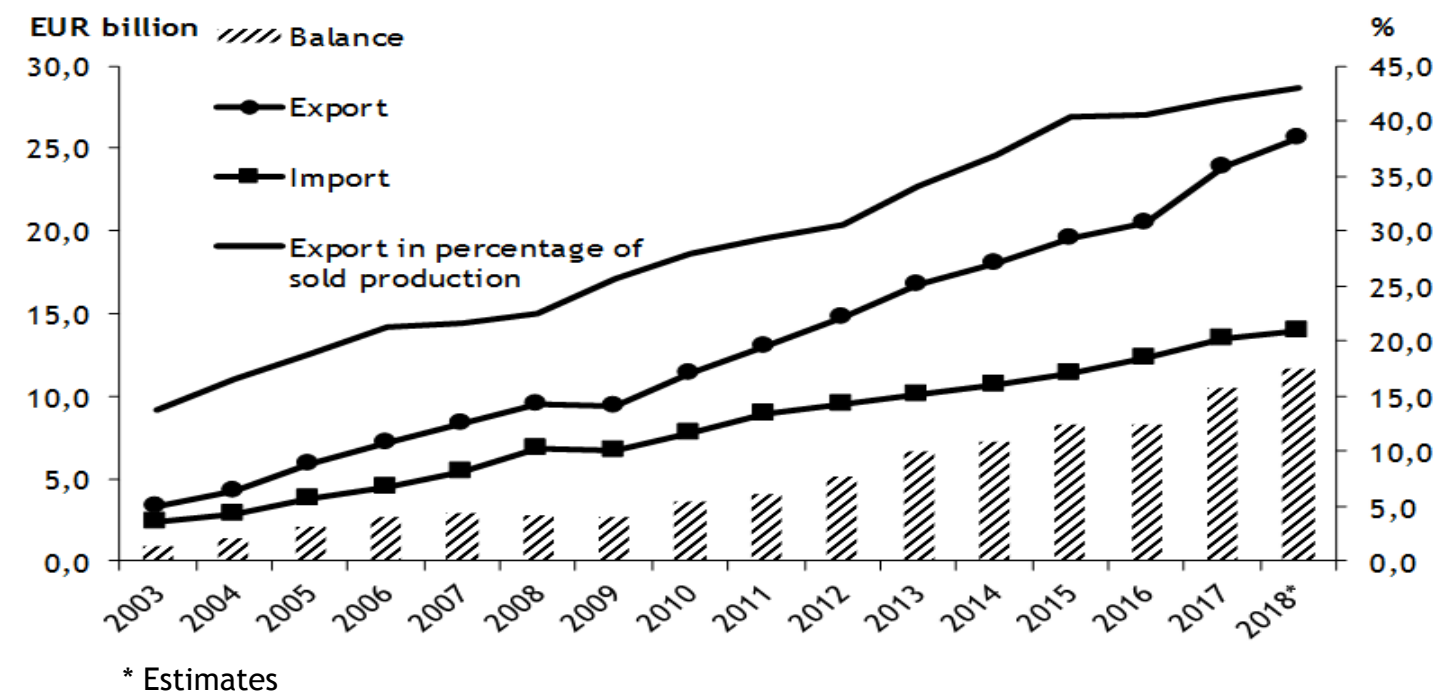

Figure 1. The development of foreign trade in food industry products

Source: own study based on unpublished data from the Central Statistical Office and the Ministry of Finance.

An important factor in the development of the food industry (especially since 2006) was the ever-increasing demand for products needed for other sectors of the economy and for highly processed food [7] (Figure 2). The production of non-food products (livestock feed, pet food, dehydrated and denaturated spirits, esters, glucose and isoglucose) was growing at a rate of, on average, $6.4 \%$ a year. The value of this production at constant prices increased almost 2.5 times and its annual changes in the years 2004-2017 were always positive. There was also the rapid development of secondary food processing (production of canned products, ready-to-eat meals, snacks, desserts, non-alcoholic beverages, fish products). The rate of its development was $4.7 \%$ a year, i.e. it was higher than of the whole food industry. The development rate of this type of processing has always been positive, even in the years of the economy-wide crisis, and the value of production of this food has almost doubled in the analysed period.

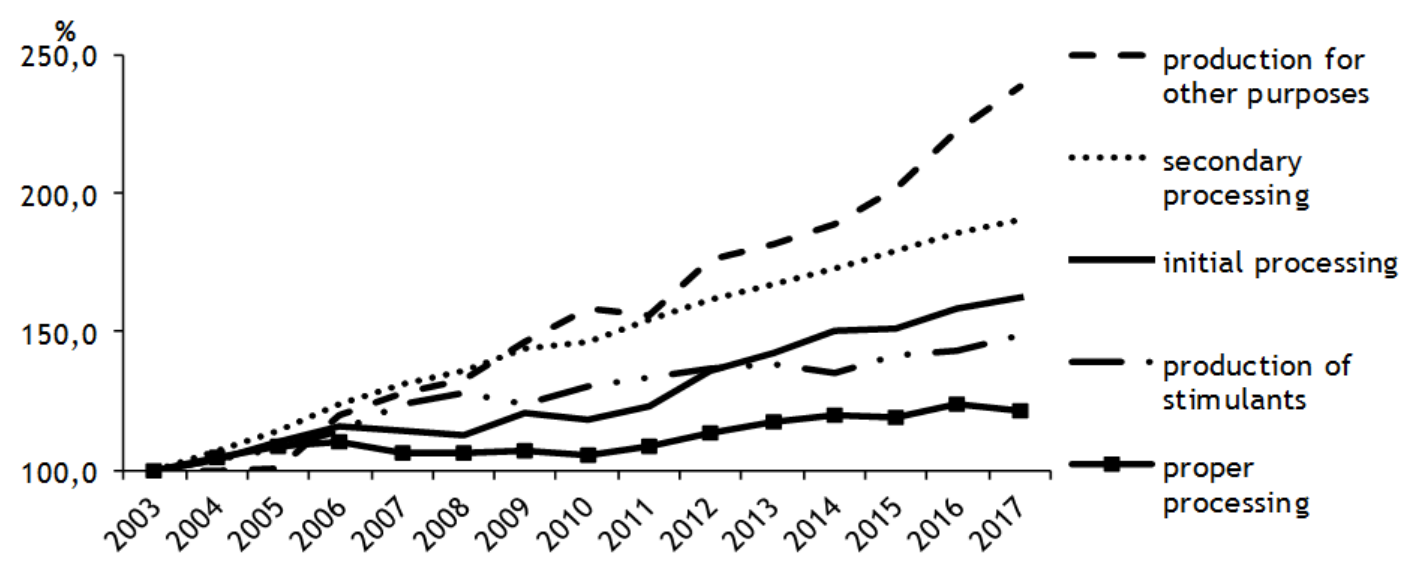

Figure 2. Dynamics of development of the main directions of industrial processing of agri-food products $(2003=100)$

Source: own study based on published and unpublished CSO data.

The relatively large production growth was achieved in so-called pre-processing of agricultural products (i.e. industrial slaughter, processing of milk, rape, sugar beet, fruit and vegetables and cereals for both food and industrial purposes). The value of this processing increased by $2 / 3$, and the annual average growth rate was lower than of the whole food 
industry and amounted to $3.5 \%$ a year. In the last five years, the development of this type of processing was accelerated, and in the analysed period the increase in this processing was faster than that of agricultural commodity production. Therefore, the share of the food industry in the development of agricultural production increased, which means that the process of industrialisation of pre-processing of agricultural products has progressed.

The production of stimulants developed more slowly than the whole food industry. Its value increased by, on average, $2.9 \%$ a year, and in the analysed period it increased by half. In general, the increase in the production of spirits, beer and tobacco products continued while the production of the wine sector decreased. The smallest increase was recorded in so-called major processing (production of coldmeats, milk, butter, oils, fish, flour, bread and frozen fruit and vegetables). The value of this processing increased by $1.4 \%$ a year, which means that in 2017 it was by about $1 / 5$ higher than in 2004. For many years it has remained stable, and only since 2011, the growth rate of this processing has been accelerated.

2. Position of Polish food producers in the food industry of the European Union

Poland is a significant food producer in the European Union. The Polish food industry occupies the sixth position according to the value of trade determined by the purchasing power of currencies, after the German, French, Italian, English and Spanish industries (Table 2). After the integration with the EU, the position of the Polish food industry has remained unchanged, but the distance between our food industry and the largest food producers in the Union has been clearly diminished. Currently, around $9 \%$ of EU food are produced in Poland, i.e. by about $2 \%$ more than in 2004, with the share in the population potential of about $7.5 \%$ and, in the economic potential - of about $3 \%$ (measured by the share in EU GDP). The value of the food industry's turnover in Poland in 2017 (at comparable prices, i.e. having regard to the purchasing power of currencies) was by about $40-43 \%$ lower than in Germany and France, by $20-25 \%$ lower than in Spain and Italy and by $5 \%$ lower than in the United Kingdom. The development rate of the food industry in Poland was one of the faster rates among EU countries, twice as fast as the European Union average, but also higher than in the EU-13.

The development of the food industry in Poland continued with a simultaneous decline in employment, which decreased by more than $2 \%$. The increase in the value of food processing turnover, with declining employment, has significantly increased the labour productivity in this industry. The labour productivity measured by the value of production in EUR per 1 employee increased by more than $2 / 3$ and has been aligned with the EU average. In 2017, the labour productivity twice higher than in the Polish food industry was recorded in the Netherlands, Ireland and Belgium, while higher by $50 \%$ - in Italy, Spain and Denmark. The labour productivity in the food industry in Poland was highest among all EU-13 countries and higher than in Portugal, United Kingdom, Sweden and Germany. The level of development of the food industry in Poland, measured in the value of turnover per 1 resident, is similar to that in Austria and Spain, slightly lower than that in Denmark, and substantially lower than that in Ireland, Belgium and the Netherlands. In this respect, it is ahead of large food producers in the EU, i.e. France, Germany and Italy and all EU-13 countries. During the membership in terms of this indicator, Poland moved up from the tenth position in 2004 to sixth in 2017.

Table 2. Polish food industry (including tobacco) in comparison with the European Union

\begin{tabular}{|c|c|c|c|c|c|c|c|c|c|c|c|c|}
\hline \multirow{3}{*}{ State } & \multicolumn{4}{|c|}{$\begin{array}{l}\text { The production value, } \\
\text { (in billon EUR) expressed by }\end{array}$} & \multirow{2}{*}{\multicolumn{2}{|c|}{$\begin{array}{l}\text { The production } \\
\text { value per } \\
1 \text { inhabitant } \\
\text { (in EUR) }\end{array}$}} & \multirow{2}{*}{\multicolumn{2}{|c|}{$\begin{array}{l}\text { Employment } \\
\text { (in thousand } \\
\text { people) }\end{array}$}} & \multirow{2}{*}{\multicolumn{2}{|c|}{$\begin{array}{c}\text { Labour } \\
\text { productivity } \\
\text { (thousand EUR } \\
\text { per employee) }\end{array}$}} & \multirow{2}{*}{\multicolumn{2}{|c|}{$\begin{array}{c}\text { Average growth rate of the value } \\
\text { of production (\% per year) } \\
\text { in years } 2005-2017\end{array}$}} \\
\hline & \multicolumn{2}{|c|}{ current prices } & \multicolumn{2}{|c|}{$\begin{array}{l}\text { comparable } \\
\text { prices }\end{array}$} & & & & & & & & \\
\hline & 2004 & 2017 & 2004 & 2017 & 2004 & 2017 & 2004 & 2017 & 2004 & 2017 & $\begin{array}{l}\text { in current } \\
\text { prices }\end{array}$ & $\begin{array}{c}\text { at comparable } \\
\text { prices }\end{array}$ \\
\hline Austria & 12,2 & 22,4 & 11,7 & 20,3 & 1444 & 2624 & 74,6 & 82,0 & 157,4 & 247,6 & 4,8 & 4,3 \\
\hline Belgium & 29,9 & 48,1 & 28,4 & 43,6 & 2727 & 3815 & 91,6 & 92,7 & 309,9 & 470,3 & 3,7 & 3,4 \\
\hline Germany & 161,9 & 191,5 & 158,3 & 178,4 & 1917 & 2173 & 824,4 & 862,4 & 192,0 & 206,8 & 1,3 & 0,9 \\
\hline Denmark & 18,8 & 23,4 & 14,0 & 17,4 & 2592 & 3035 & 78,8 & 55,3 & 177,4 & 315,6 & 1,7 & 1,7 \\
\hline Spain & 79,9 & 113,6 & 87,6 & 125,8 & 2001 & 2714 & 363,5 & 388,8 & 240,9 & 323,5 & 2,7 & 2,8 \\
\hline France & 143,1 & 184,6 & 128,7 & 168,4 & 2143 & 2592 & 616,6 & 607,1 & 208,7 & 277,3 & 2,0 & 2,1 \\
\hline Finland & 8,2 & 10,5 & 7,1 & 8,4 & 1359 & 1521 & 37,4 & 37,1 & 190,1 & 227,4 & 1,9 & 1,3 \\
\hline Grace & 10,0 & 13,3 & 12,1 & 16,2 & 1099 & 1452 & 67,9 & 99,7 & 178,9 & 162,5 & 2,2 & 2,3 \\
\hline Ireland & 20,3 & 27,0 & 17,1 & 24,0 & 4250 & 5040 & 45,4 & 50,8 & 376,2 & 472,8 & 2,2 & 2,6 \\
\hline Italy & 109,4 & 134,2 & 107,7 & 135,9 & 1872 & 2289 & 347,5 & 366,6 & 310,0 & 370,7 & 1,6 & 1,8 \\
\hline Luxembourg & 0,8 & 0,9 & 0,7 & 0,7 & 1542 & 1199 & 5,2 & 5,7 & 131,8 & 125,8 & 0,9 & 0,0 \\
\hline
\end{tabular}


Continued tab. 2

\begin{tabular}{|c|c|c|c|c|c|c|c|c|c|c|c|c|}
\hline Netherlands & 48,9 & 70,7 & 45,5 & 62,9 & 2796 & 3692 & 127,2 & 129,2 & 358,0 & 486,9 & 2,9 & 2,5 \\
\hline Portugal & 11,2 & 15,6 & 14,0 & 19,2 & 1330 & 1859 & 100,8 & 108,1 & 138,8 & 177,2 & 2,6 & 2,5 \\
\hline Sweden & 13,6 & 16,2 & 11,3 & 12,4 & 1257 & 1251 & 65,3 & 53,7 & 172,7 & 231,1 & 1,4 & 0,7 \\
\hline $\begin{array}{l}\text { United } \\
\text { Kingdom }\end{array}$ & 111,0 & 120,5 & 92,3 & 107,3 & 1550 & 1621 & 470,9 & 499,6 & 196,0 & 214,8 & 0,6 & 1,2 \\
\hline Poland & 29,3 & 59,8 & 61,3 & 102,0 & 1606 & 2672 & 423,5 & 414,5 & 144,8 & 246,0 & 5,6 & 4,0 \\
\hline $\begin{array}{l}\text { Czech } \\
\text { Republic }\end{array}$ & 9,8 & 12,3 & 18,3 & 18,0 & 1792 & 1695 & 132,9 & 104,8 & 138,0 & 171,5 & 1,8 & $-0,1$ \\
\hline Hungary & 9,6 & 11,6 & 15,9 & 18,8 & 1574 & 1934 & 128,4 & 103,0 & 123,7 & 182,6 & 1,5 & 1,3 \\
\hline Slovakia & 2,4 & 3,7 & 4,8 & 5,5 & 892 & 1010 & 42,8 & 40,1 & 111,9 & 137,1 & 3,4 & 1,1 \\
\hline Slovenia & 1,7 & 2,0 & 2,4 & 2,4 & 1202 & 1154 & 20,9 & 15,6 & 113,3 & 154,2 & 1,3 & 0,0 \\
\hline Lithuania & 1,9 & 4,0 & 3,9 & 6,3 & 1134 & 2180 & 53,3 & 40,6 & 73,9 & 154,9 & 5,9 & 3,8 \\
\hline Latvia & & 1,8 & 2,5 & 2,6 & 1081 & 1333 & 35,8 & 23,2 & & 111,6 & & 0,3 \\
\hline Estonia & 0,9 & 1,7 & 1,5 & 2,3 & 1118 & 1756 & 17,7 & 14,7 & 87,0 & 156,0 & 5,0 & 3,3 \\
\hline Romania & 6,2 & 11,3 & 16,8 & 22,1 & 780 & 1123 & 203,6 & 182,5 & 82,5 & 121,0 & 4,7 & 2,1 \\
\hline Bulgaria & 2,8 & 6,0 & 7,9 & 12,4 & 1024 & 1750 & 105,6 & 93,0 & 75,0 & 133,4 & 6,0 & 3,5 \\
\hline Cyprus & 1,2 & 1,5 & 1,4 & 1,7 & 1869 & 1441 & 13,6 & 12,8 & 102,3 & 132,1 & 1,7 & 1,5 \\
\hline Malta & 0,4 & 0,4 & 0,6 & 0,5 & 1496 & 1160 & 3,9 & 3,5 & 146,3 & 147,7 & 0,0 & $-1,4$ \\
\hline Croatia & & 4,7 & 7,1 & 7,3 & 1579 & 1743 & 66,0 & 59,6 & & 122,4 & & 0,2 \\
\hline UE-28 & 845,4 & 1113,3 & 881,0 & 1142,8 & 1791 & 2250 & 4565,2 & 4546,8 & 190,9 & 251,3 & 2,1 & 2,0 \\
\hline UE-15 & 779,2 & 992,4 & 736,6 & 940,9 & 1919 & 2334 & 3317,2 & 3438,7 & 222,0 & 273,6 & 1,9 & 1,9 \\
\hline UE-13 & 66,3 & 120,9 & 144,4 & 201,8 & 1339 & 1926 & 1248,0 & 1108,1 & 108,1 & 182,2 & 4,7 & 2,6 \\
\hline
\end{tabular}

Source: own study based on calculations by M. Tereszczuk made according to Eurostat data.

Conclusions. After the integration of Poland with the European Union, there was a clear acceleration in the development of the Polish food industry. However, in the individual phases of integrating our economy with the EU, the impact of two main factors of the development of this industry - domestic and export demand - was different. In the first years of membership, the production recovery was triggered by both the increase in the domestic demand resulting from accelerating the Polish economic development and the growth of population income, as well as from the fast-growing food export. In the following years, the export be-

\section{Literature}

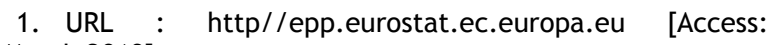
20 March 2019].

2. Ambroziak $t$. Relative prices in the Polish export of agrifood products to the European Union countries, [in:] Competitiveness of Polish food producers and its determinants (3) Ed. I. Szczepaniak, "Monographs of the Multi-Annual Programme 2015-2019" series, No 67, IAFE-NRI, Warsaw 2017. Pp. 81-106.

3. Drożdż J., Tereszczuk M., Mroczek R. Socio-economic conditions for improving the labour productivity in the Polish food industry against a background of the European Union countries, [in:] Competitiveness of the economy in the context of social policy actions - national perspective, ed. By A. Kowalski, M. Wigier, "Monographs of the Multi-Annual Programme 2015-2019" series, No 26, IAFE-NRI, Warsaw 2016. Pp. 110-125.

4. Firlej $K$. Development of the agri-food industry in the sector of agribusiness and its determinants, Publishing House of the Krakow University of Economics), Krakow 2008. Pp. 52-62.

5. Mroczek $R$. Food Industry, [in:] Processing of plant products in Poland in the years 2010-2015 and 2004, ed. by R. Mroczek, "Monographs of the Multi-Annual Programme 20152019" series, No 39, IAFE-NRI, Warsaw 2016. Pp. 123-138.

6. Mroczek R. Food Industry, [in:] Processing of animal products in Poland in the years 2010-2016 ed. by J. Drożdż, R. Mroczek, "Monographs of the Multi-Annual Programme 20152019" series, No 68, IAFE-NRI, Warsaw 2017. Pp. 116-141.

7. Mroczek R. Food Industry, [in:] Production of stimulants, non-alcoholic beverages, sweets and other food in Poland in the years 2010-2017 ed. by J. Drożdż, R. Mroczek, "Monographs of the Multi-Annual Programme 2015-2019" series, No 87, IAFE-NRI, Warsaw 2018. Pp. 146-166. came a basis for the development of the sector, but since 2016 we have also recorded the increase in the domestic food demand. The development of food processing in Poland now has stable foundations created by the increase in the export and domestic demand. As a result of the development of the sector, the position of the Polish food industry in the EU industry has been strengthened and the distance to the EU food processing leaders has diminished. The share of the Polish food industry in the EU industry is significantly greater than in the economic and population potential of the European Union.

\section{References}

1. Eurostat. European Commission. Retrieved from: http//epp.eurostat.ec.europa.eu [In English].

2. Ambroziak, Ł. (2017). Relative prices in the Polish export of agri-food products to the European Union countries. Competitiveness of Polish food producers and its determinants (pp. 81-106). Warsaw: IAFE-NRI [In English].

3. Drożdż, J., Tereszczuk, M., \& Mroczek, R. (2016). Socio-economic conditions for improving the labour productivity in the Polish food industry against a background of the European Union countries. Competitiveness of the economy in the context of social policy actions - national perspective. (pp. 110-125). Warsaw: IAFE-NRI [In English].

4. Firlej, K. (2008). Development of the agri-food industry in the sector of agribusiness and its determinants. Krakow: Publishing House of the Krakow University of Economics [In English].

5. Mroczek, R. (2016). Food industry. Processing of plant products in Poland in the years 2010-2015 and 2004. (pp. 123138). Warsaw: IAFE-NRI [In English].

6. Mroczek, R. (2017). Food Industry. Processing of animal products in Poland in the years 2010-2016. (pp. 116-141). Warsaw: IAFE-NRI [In English].

7. Mroczek, R. (2018). Food industry. Production of stimulants, non-alcoholic beverages, sweets and other food in Poland in the years 2010-2017. (pp. 146-166). Warsaw: IAFE-NRI [In English].

8. Plaskacz, S., Podgórska, M., \& Klimkowska, J. (1998; 2005). Compound interest. Toruń: TNOiK; Financial mathematics. Warsaw: PWN [In English]. 
8. Plaskacz S., Podgórska M., Klimkowska J. Compound interest, TNOiK, Toruń 1998; Financial mathematics, PWN, Warsaw 2005.

9. Szczepaniak I. Comparative advantages in Polish trade in agri-food products, [in:] Competitiveness of Polish food producers and its determinants (3) ed. by I. Szczepaniak, "Monographs of the Multi-Annual Programme 2015-2019" series, No 67, IAFE-NRI, Warsaw 2017. Pp. 45-80.
9. Szczepaniak, I. (2017). Comparative advantages in Polish trade in agri-food products. Competitiveness of Polish food producers and its determinants (pp. 45-80). Warsaw: IAFENRI [In English].

\section{Дрозд Я. Розвиток харчової промисловості Польщі протягом їі членства в Європейському Союзі}

Mета статmі - висвітлити вплив членства Польщі в Європейському Союзі на розвиток виробництва харчових продуктів, напоїв та тютюнових виробів.

Методика дослідження. У процесі дослідження використано такі методи: абстрактний та логічний, системного аналізу з використанням математичної методології, індукції та дедукції.

Результати дослідження. Здійснено економічну оцінку польської харчової промисловості порівняно з іншими країнами Європейського Союзу. Темпи розвитку харчової промисловості під час членства Польщі в Європейському Союзі були досить високими, хоча й дещо нижчими, ніж у цілому по промисловості. За аналізований період (2004-2018 рр.) виробництво продовольства зросло в середньому на 4,2\% в рік порівняно з 5,5\% для всієї промисловості. Польська харчова промисловість посідає шосту позицію за обсягом торгівлі, що визначається купівельною спроможністю валют, після німецької, французької, італійської, англійської та іспанської промисловості. Після інтеграції до ЄС позиція польської харчової промисловості залишилася незмінною, але відстань між харчовою промисловістю Польщі та найбільшими виробниками продовольства в ЄС зменшилася. Натепер в Польщі виробляється до 9\% продуктів харчування ЄС, причому частка в потенціалі населення становить майже 7,5\%, а в економічному потенціалі - близько 3\% (виміряно часткою ВВП ЄС). Вартість обороту харчової промисловості в Польщі в 2017 р. була приблизно на 40-43\% нижчою, ніж у Німеччині та Франції, на 20-25\% нижче, ніж в Іспанії та Італії та на 5\% нижче, ніж у Великобританії. Разом із тим темпи розвитку харчової промисловості в Польщі є одними з найвищих серед країн ЄС, що вдвічі вище, ніж у середньому по Європейському Союзу, а також вищі, ніж у країнах ЄС-13.

Елементи наукової новизни. Проаналізовано ситуацію з розвитком харчової промисловості Польщі в умовах європейської інтеграції.

Практична значущість. Результати дослідження можуть бути використані продовольчим сектором, операторами ринку і сільськогосподарськими підприємствами ЄС та України. Табл.: 2. Рис.: 2. Бібліогр.: 9.

Ключові слова: харчова промисловість; харчові продукти; напої та тютюнові вироби; реалізована продукція харчовоі промисловості; Польща; Європейський Союз.

Дрозд Ядвіга - асистент відділу економіки харчової промисловості, Інститут економіки сільського господарства та продовольства - Державний дослідницький інститут (Польща, м. Варшава, вул. Свентокшиська, 20) E-mail: jadwiga.drozdz@ierigz.waw.pl

\section{Дрозд Я. Развитие пищевой промышленности Польши в течение её членства в Европейском Союзе}

Цель статьи - осветить влияние членства Польши в Европейском Союзе на развитие производства пищевых продуктов, напитков и табачных изделий.

Методика исследования. В процессе исследования использованы такие методы: абстрактный и логический, системного анализа с использованием математической методологии, индукции и дедукции.

Результаты исследования. Осуществлена экономическая оценка польской пищевой промышленности в сравнении с другими странами Европейского Союза. Темпы развития пищевой промышленности во время членства Польши в Европейском Союзе были достаточно высокими, хотя и немного ниже, чем в челом по промышленности. За анализируемый период (2004-2018 г2.) производство продовольствия возросло в среднем на 4,2\% в год в сравнении с 5,5\% для всей промышленности. Польская пищевая промышленность занимает шестую позицию по объему торговли, что определяется покупательной способностью валют, после немецкой, французской, итальянской, английской и испанской промышленности. После интеграции в ЕС позиция польской пищевой промышленности осталась неизменной, но расстояние между пищевой промышленностью Польши и крупнейшими производителями продовольствия в ЕС уменьшилось. В настоящее время в Польше производится до 9\% продуктов питания ЕС, причем доля в потенциале населения составляет почти 7,5\%, а в экономическом потенциале - около 3\% (измерено долей ВВП ЕС). Стоимость оборота пищевой промышленности в Польше в 2017 г. была примерно на 40-43\% ниже, чем в Германии и Франции, на 20-25\% ниже, чем в Испании и Италии и на 5\% ниже, чем в Великобритании. Вместе с тем темпы развития пищевой промышленности в Польше являются одними из самых высоких среди стран ЕС, что в два раза выше, чем в среднем по Европейскому Союзу, а также выше, чем в странах ЕC-13.

Элементы научной новизны. Проанализирована ситуация с развитием пищевой промышленности Польши в условиях европейской интеграции.

Практическая значимость. Результаты исследования могут быть использованы продовольственным сектором операторами рынка и сельскохозяйственными предприятиями EC и Украины. Табл.: 2. Илл.: 2. Библиогр.: 9.

Ключевые слова: пищевая промышленность; пищевые продукты; напитки и табачные изделия; реализованная продукция пищевой промышленности; Польша; Европейский Союз.

Дрозд Ядвига - ассистент отдела экономики пищевой промышленности, Институт экономики сельского хозяйства и продовольствия - Государственный исследовательский институт (Польша, г. Варшава, ул. Свентокшиска, 20) E-mail: jadwiga.drozdz@ierigz.waw.pl

The article has been received 11.04.2019

Revision: 02.05.2019

Бібліографічний опис для цитування:

Drożdż Jadwiga. Development of the food industry in Poland during the membership in the European Union. Економіка АПК. 2019. № 5. С. 87 - 93. 